\title{
Efek Konseling Apoteker Terhadap Kepatuhan Minum Obat dan Kualitas Hidup Penderita Skizofrenia di Rumah Sakit Jiwa Menur Surabaya
}

\author{
Verra Yuliana $^{1}$, Adji P. Setiadi ${ }^{1}$, Josephine P. Ayuningtyas ${ }^{2}$ \\ ${ }^{1}$ Fakultas Farmasi, Universitas Surabaya, Surabaya, Indonesia \\ ${ }^{2}$ Rumah Sakit Jiwa Menur, Surabaya, Indonesia
}

\begin{abstract}
Abstrak
Skizofrenia merupakan gangguan psikiatri yang kompleks ditandai dengan gangguan kognitif, emosi, persepsi, berpikir dan berperilaku. Penelitian ini dilakukan untuk mengetahui perbedaan tingkat kepatuhan minum obat pasien skizofrenia sebelum dan setelah diberikan konseling oleh apoteker serta untuk mengetahui kualitas hidupnya. Metode penelitian ini adalah one-grup pretest-posttest yang bersifat prospektif. Pengambilan sampel terhadap responden sesuai kriteria inklusi dilakukan di Instalasi Farmasi Rumah Sakit Jiwa Menur pada bulan Mei sampai Juli tahun 2018. Sebelum pengambilan data dilakukan, responden yang sesuai dengan kriteria inklusi diberikan penjelasan tentang tujuan dan gambaran penelitian. Apabila setuju menjadi subjek, pasien atau keluarganya diwajibkan mengisi informed consent. Wawancara sesuai kuesioner Medication Adherence Rating Score (MARS) dan The World Health Organization Quality of Life (WHOQOL)-BREF pada responden dilakukan dua kali, yakni pada kedatangan pertama sebelum dilakukan konseling dan satu bulan kemudian saat subjek kontrol kembali. Total responden sebanyak 100 orang. Data dianalisis menggunakan uji beda (uji T). Hasil penelitian menunjukkan terdapat perbedaan bermakna pada kepatuhan minum obat responden antara prepost konseling oleh apoteker $(\mathrm{p}=0,033)$. Hasil penelitian ini menunjukkan bahwa kualitas hidup subjek memiliki perbedaan bermakna hanya terkait domain lingkungan $(p=0,00)$, sedangkan pada domain fisik, mental dan sosial tidak memiliki perbedaan bermakna ( $\mathrm{p}>0,05)$.
\end{abstract}

Kata kunci: Kepatuhan, kualitas hidup, MARS, skizofrenia, WHOQOL-BREF

\section{Effect of Pharmacist Counseling on Medication Adherence and Quality of Life of Schizophrenic Patients in Menur Mental Hospital, Surabaya}

\begin{abstract}
Schizophrenia is a complex psychiatric disorder characterized by cognitive, emotion, perception, thinking, and behavior impairment. This research was conducted to determine the difference in level of compliance with schizophrenic patients before and after counseling by pharmacist, as well as to know their quality of life. The research method was one-group pretest-posttest with perspective design. Sampling of samples who met the inclusion criteria was done in the pharmaceutical installation of Menur Psychiatric Hospital from May to July 2018. Before data retrieval was done, all samples appropriated with the inclusion criteria were given an explanation about the purpose and description of the study, and after agreeing to be the subject, the patients or their family were obliged to fill informed consent. Interviews according to the Medication Adherence Rating Score (MARS) dan The World Health Organization Quality of Life (WHOQOL)-BREF questionnaires were done twice; the first was done upon arrival before counseling and the later was one month upon returning for control. Total of subjects was 100 people. The obtained data was analyzed using a different test (t-test). The result showed that there was a meaningful difference in patients' compliance in taking drugs between pre and post counseling by the pharmacist ( $p=0.033$ ). In terms of patients' quality of life, results showed that the meaningful difference were only related to environmental domain $(p=0.00)$, whereas no meaningful differences found on physical, mental and social domains ( $p>0.05)$.
\end{abstract}

Keywords: Adherence, MARS, quality of life, schizophrenia, WHOQOL-BREF 


\section{Pendahuluan}

Kesehatan jiwa menurut undang-undang dapat diartikan sebagai kondisi saat seorang individu dapat berkembang baik secara fisik, mental, spiritual dan sosial sehingga individu tersebut sadar akan kemampuannya sendiri, dapat mengatasi tekanan, dapat bekerja secara produktif, dan memberikan kontribusi untuk komunitasnya. ${ }^{1}$ Menurut data World Health Organization (WHO), di dunia ini terdapat sekitar 35 juta orang yang menderita depresi, 60 juta orang yang menderita bipolar, 35 juta orang menderita skizofrenia dan 47,5 juta menderita demensia. ${ }^{2}$ Riset Kesehatan Dasar (Riskesdas) tahun 2013 menunjukkan fakta bahwa 2 orang dari 1000 orang atau 1,7 per mil mengalami gangguan jiwa berat termasuk skizofrenia. $^{3}$

Skizofrenia merupakan penyakit kronis yang mengganggu fungsi otak terutama pada proses berpikir, kehidupan sosial, kemampuan pada aspek bahasa dan emosi, serta kemampuan untuk menerima kenyataan secara akurat. ${ }^{4}$ Keberhasilan terapi dipengaruhi oleh jenis obat, pengetahuan keluarga serta peran serta pasien dalam pengobatan, yaitu kepatuhan penderita dalam pengobatan skizofrenia yang juga merupakan hal yang paling penting. ${ }^{5} \mathrm{Di}$ Rumah Sakit Jiwa Menur di Surabaya, ratarata kejadian pasien kambuh yakni sebesar $53,93 \%$ pada setiap bulannya. Separuh dari pasien yang dirawat di rumah sakit merupakan pasien yang pernah menjalani pengobatan skizofrenia sebelumnya. Faktor-faktor yang menjadi penyebab kekambuhan yakni pasien yang tidak patuh minum obat, ketika merasa sehat langsung menghentikan pengobatan, tidak berobat ke dokter secara rutin, berada di lingkungan keluarga dan masyarakat yang acuh serta adanya masalah kehidupan. Bentuk ketidakpatuhan pasien dalam minum obat yaitu tidak minum obat atau menghentikan obat sendiri tanpa persetujuan dari dokter.

Pharmaceutical care sebagai perubahan paradigma fungsi apoteker dari yang semula hanya berfokus terhadap produk (obat) menjadi berorientasi kepada pasien, merupakan salah satu upaya yang dilakukan untuk meningkatkan kepatuhan minum obat pasien. ${ }^{6}$ Salah satu bentuk pharmaceutical care yang dimaksud dalam hal ini berupa pemberian konseling terhadap pasien skizofrenia tentang obat-obat yang digunakan untuk terapi penyakit mereka. ${ }^{7}$ Pemberian konseling dapat meningkatkan nilai apoteker dalam memberikan layanan. ${ }^{8}$ Selain itu, pemberian konseling juga dapat meningkatkan pengetahuan pasien. ${ }^{9,10}$

Berbagai penelitian menunjukkan bahwa intervensi konseling pengobatan berbasis masyarakat telah menghasilkan peningkatan kepatuhan pasien terhadap antidepresan dan antipsikotik. ${ }^{11}$ Sebuah penelitian di Amerika pada tahun 2010 menyatakan bahwa apoteker lebih memilih memberikan konseling kepada pasien dengan penyakit fisik (misalnya asma) dibandingkan pasien dengan penyakit jiwa termasuk skizofrenia. ${ }^{8}$ Banyaknya hambatan yang dijumpai dalam melakukan konseling terhadap pasien dengan gangguan mental merupakan alasan bagi apoteker untuk tidak melakukan konseling terhadap pasien dengan gangguan mental. ${ }^{12,13}$ Pemberian konseling pada pasien gangguan mental menjadi tantangan tersendiri, sebab intervensi untuk memperbaiki konseling terhadap pasien kesehatan mental harus berfokus pada peningkatan komunikasi dan pengetahuan apoteker terhadap penyakit maupun terapi yang diberikan. ${ }^{12}$

Kepatuhan pasien penderita skizofrenia dalam minum obat tentunya dapat mencegah terjadinya kekambuhan pada pasien dan juga meningkatkan kualitas hidup pasien sendiri. ${ }^{14}$ Dengan meningkatnya kualitas hidup pasien, diharapkan bahwa kepuasan pasien terhadap pelayanan kesehatan akan meningkat pula. Peneliti tertarik mengkaji efek konseling oleh apoteker terhadap kepatuhan minum obat dan kualitas hidup penderita skizofrenia di Rumah Sakit Jiwa Menur Surabaya dengan 
tujuan mengetahui tingkat kepatuhan minum obat pasien skizofrenia sebelum dan setelah diberikan konseling oleh apoteker di Rumah Sakit Jiwa Menur serta untuk mengetahui kualitas hidupnya.

\section{Metode}

Desain penelitian

Penelitian ini merupakan penelitian quasi experimental dengan one-group pretest-post test design yang bersifat prospektif.

\section{Responden penelitian}

Responden penelitian adalah pasien rawat jalan Rumah Sakit Jiwa Menur Surabaya yang memenuhi kriteria inklusi penelitian. Kriteria inklusi penelitian ini adalah pasien dengan diagnosis skizofrenia yang menjalani rawat jalan di Rumah Sakit Jiwa Menur, laki-laki atau perempuan yang berusia 16-60 tahun, serta bersedia untuk menjadi responden dan menandatangani informed consent. Kriteria ekslusi adalah pasien kiriman dinas sosial. Kriteria drop out yakni pasien yang menolak untuk memberikan keterangan pada saat wawancara kedua atau pasien tidak kembali berobat satu bulan kemudian sesuai dengan waktu yang telah ditentukan. Dari 106 orang yang masuk kriteria inklusi, terdapat 6 orang drop out yang disebabkan 4 orang dinyatakan Masuk Rumah Sakit (MRS) sebelum waktu kembali yang telah ditetapkan dan 2 orang lainnya tidak kembali pada saat waktu yang ditentukan.

Instrumen penelitian

Alat pengumpul data pada penelitian ini yaitu kuesioner Medication Adherence Rating Score (MARS) dan kuesioner The World Health Organization Quality of Life (WHOQOL)BREF versi Bahasa Indonesia.

Uji validitas dan realibititas

Uji validitas dan uji reliabilitas dilakukan terhadap kuesioner MARS dan WHOQOLBREF. Validasi isi kuesioner dilakukan pada 30 orang pasien di luar responden yang diuji. Kuesioner MARS dan kuesioner WHOQOLBREF yang digunakan adalah kuesioner versi Bahasa Indonesia. ${ }^{15,16}$

\section{Pelaksanaan konseling}

Konseling dilakukan pada pertemuan pertama setelah wawancara pasien yang mengacu pada kuesioner MARS dan WHOQOL-BREF. Konseling diberikan oleh apoteker yang bekerja di Rumah Sakit Jiwa Menur dan sebelumnya telah diberi penjelasan mengenai maksud, tujuan dan cara melakukan konseling sesuai standar yang ada. Adapun materi konseling meliputi penjelasan tentang tujuan konseling diberikan, obat yang diterima pasien, apa yang harus dilakukan apabila pasien lupa minum obat, hal-hal yang perlu dihindari saat minum obat, efek samping yang mungkin muncul dan cara mengatasinya, cara menyimpan obat yang benar dan memastikan bahwa pasien memahami semua yang telah dijelaskan. Waktu yang diperlukan untuk konseling adalah 5-10 menit. Satu bulan setelah dilakukan konseling, dilakukan wawancara kembali berdasarkan kuesioner MARS dan WHOQOL.

\section{Analisis data}

Sebelum dilakukan analisis terhadap data, terlebih dahulu data dilakukan uji normalitas Komolgorov-Smirnov dengan program IBM SPSS Statistics versi 23. Hasil dari perhitungan menunjukkan sampel berdistribusi normal.

Data demografi responden seperti usia, jenis kelamin, tingkat pendidikan, pekerjaan, status dari perkawinan, lama menderita skizofrenia, pernah tidaknya mendapat informasi tentang skizofrenia, jenis obat yang dikonsumsi, jumlah obat yang dikonsumsi serta kombinasi obat yang digunakan ditampilkan dalam persentase. Hasil nilai mean kepatuhan dan kualitas hidup pre-post konseling dilakukan uji beda (t-test) dengan program IBM SPSS Statistics versi 23. 


\section{Hasil}

Penelitian ini telah mendapatkan persetujuan etik dari Komite Etik Penelitian Kesehatan Rumah Sakit Jiwa Menur dengan nomor 072/3833/305/2018. Jumlah sampel penelitian ini sebanyak 100 orang.
Karakteristik responden

Berdasarkan Tabel 1, dapat diketahui bahwa usia responden terbanyak adalah 36-55 tahun (49\%) dengan jenis kelamin laki-laki (64\%) dan tingkat pendidikan terbanyak yaitu SMA/ SLTA (42\%). Sebanyak 59\% responden tidak bekerja, 16\% berwiraswasta dengan berjualan

Tabel 1 Data Demografi Responden

\begin{tabular}{|c|c|c|}
\hline Faktor Demografi & Jumlah & Persentase \\
\hline \multicolumn{3}{|l|}{ Usia (tahun) } \\
\hline$<21$ & 2 & $2 \%$ \\
\hline $21-35$ & 35 & $35 \%$ \\
\hline $36-55$ & 49 & $49 \%$ \\
\hline$>55$ & 14 & $14 \%$ \\
\hline \multicolumn{3}{|l|}{ Jenis Kelamin } \\
\hline Laki-laki & 36 & $36 \%$ \\
\hline Perempuan & 64 & $64 \%$ \\
\hline \multicolumn{3}{|l|}{ Tingkat Pendidikan } \\
\hline $\mathrm{SD}$ & 14 & $14 \%$ \\
\hline SMP/SLTP & 27 & $27 \%$ \\
\hline SMA/SLTA & 42 & $42 \%$ \\
\hline Perguruan tinggi & 16 & $16 \%$ \\
\hline Tidak sekolah & 1 & $1 \%$ \\
\hline \multicolumn{3}{|l|}{ Pekerjaan } \\
\hline Wiraswasta & 16 & $16 \%$ \\
\hline Petani & 4 & $4 \%$ \\
\hline Karyawan swasta & 10 & $10 \%$ \\
\hline Tidak bekerja & 59 & $59 \%$ \\
\hline Lain-lain & 11 & $11 \%$ \\
\hline \multicolumn{3}{|l|}{ Status Perkawinan } \\
\hline Belum Menikah & 51 & $51 \%$ \\
\hline Menikah & 36 & $36 \%$ \\
\hline Cerai & 13 & $13 \%$ \\
\hline \multicolumn{3}{|c|}{ Lama Menderita Skizofrenia (tahun) } \\
\hline 1 & 12 & $12 \%$ \\
\hline $1-5$ & 32 & $32 \%$ \\
\hline$>5$ & 56 & $56 \%$ \\
\hline \multicolumn{3}{|c|}{ Mendapatkan Informasi tentang Skizofrenia } \\
\hline Pernah & 42 & $42 \%$ \\
\hline Tidak pernah & 58 & $58 \%$ \\
\hline \multicolumn{3}{|c|}{ Jenis Obat yang Dikonsumsi } \\
\hline Kombinasi & 92 & $92 \%$ \\
\hline Tunggal & 8 & $8 \%$ \\
\hline \multicolumn{3}{|c|}{ Jumlah Obat yang Dikonsumsi } \\
\hline 1 macam & 6 & $6 \%$ \\
\hline 2 macam & 26 & $26 \%$ \\
\hline 3 macam & 51 & $51 \%$ \\
\hline 4 macam & 17 & $17 \%$ \\
\hline
\end{tabular}


Tabel 2 Persentase Tingkat Kepatuhan Minum Obat Penderita Skizofrenia Rawat Jalan Rumah Sakit Jiwa Menur Pre-Post Dilakukan Konseling oleh Apoteker

\begin{tabular}{lcc}
\hline \multirow{2}{*}{ Kategori Tingkat Kepatuhan } & \multicolumn{3}{c}{ Persentase (\%) } \\
\cline { 2 - 3 } & Pretest & Posttest \\
\hline Kepatuhan Rendah & 63 & 59 \\
Kepatuhan Sedang & 36 & 40 \\
Kepatuhan Tinggi & 1 & 1 \\
\hline
\end{tabular}

makanan atau minuman, $4 \%$ sebagai petani, $10 \%$ sebagai karyawan swasta yaitu sebagai buruh pabrik dan karyawan toko. Sebanyak $11 \%$ responden sisanya melakukan pekerjaan yang tidak tetap seperti mengamen, asisten rumah tangga, pemulung, membantu berjualan prancangan keluarga mereka dan supir ojek online.

Diketahui bahwa sebanyak 51\% responden belum menikah, 36\% sudah menikah dan 13\% sudah bercerai. Lama responden menderita skizofrenia terbanyak yaitu lebih dari 5 tahun (56\%), dan $42 \%$ responden menyatakan pernah mendapatkan informasi tentang skizofrenia. Terapi obat yang dikonsumsi oleh responden merupakan terapi kombinasi (92\%) dengan 3 macam obat (51\%).

Hasil uji validitas dan realibilitas Hasil uji menyatakan bahwa kuesioner MARS dan kuesioner WHOQOL-BREF valid dan reliabel digunakan. Nilai $r$ hitung lebih besar dari $r$ tabel untuk kuesioner MARS dan nilai Cronbach Alpha kuesioner WHOQOL-BREF sebesar 0,882 .

Kepatuhan minum obat pre-post konseling Tingkat kepatuhan pada penelitian ini diperoleh dari nilai kuesioner MARS setiap responden dengan kategori nilai $<5=$ kepatuhan rendah; 5-7 =kepatuhan sedang; dan $>7=$ kepatuhan tinggi. Hasil persentase tingkat kepatuhan dapat dilihat pada Tabel 2.

Pengaruh konseling apoteker

Hasil uji beda (t-test) menyatakan bahwa terdapat perbedaan bermakna antara mean tingkat kepatuhan pre-post konseling oleh apoteker dengan nilai $\mathrm{p}=0,033$ (Tabel 3) dan terdapat perbedaan bermakna antara mean kualitas hidup responden pre-post konseling pada domain lingkungan $(\mathrm{p}<0,05)$, namun pada domain fisik, mental dan sosial tidak terdapat perbedaan bermakna $(p>0,05)$ (Tabel 4).

\section{Pembahasan}

Penelitian ini membuktikan bahwa pemberian konseling oleh apoteker berpengaruh signifikan terhadap kepatuhan minum obat dan kualitas hidup penderita skizofrenia. Pengambilan data penelitian dilakukan dengan wawancara pada responden yang dilakukan sebanyak dua kali; pertama, sebelum dilakukan konseling, dan kedua, pada rentang waktu 1 bulan setelah dilakukan konseling. Rentang waktu 1 bulan ini dipilih karena sebagian besar responden merupakan pasien BPJS dari berbagai daerah di Jawa Timur dengan kondisi penyakit kronis yang mempunyai aturan tetap dalam waktu pengambilan obat BPJS nya. Untuk menjaga agar pasien tidak terpengaruh oleh

Tabel 3 Hasil Uji T Tingkat Kepatuhan Minum Obat Pre-Post Dilakukan Konseling oleh Apoteker

\begin{tabular}{lcccccc}
\hline \multicolumn{1}{c}{ Tingkat Kepatuhan } & Mean & N & Correlation & Sig. & T & Sig. (2-tailed) \\
\hline Pretest & 4,03 & 100 & 0,500 & 0,000 & $-2,159$ & 0,033 \\
Posttest & 4,32 & 100 & & & & \\
\hline
\end{tabular}

Keterangan: Tabel ini menunjukkan adanya pengaruh konseling apoteker terhadap kepatuhan minum obat 
Tabel 4 Kualitas Hidup Penderita Skizofrenia (4 Domain) Pre-Post Dilakukan Konseling Apoteker

\begin{tabular}{|c|c|c|c|c|c|c|c|}
\hline \multirow{2}{*}{ Kualitas Hidup } & \multicolumn{2}{|c|}{ Mean } & \multirow{2}{*}{$\mathbf{N}$} & \multirow{2}{*}{ Correlation } & \multirow{2}{*}{ Sig. } & \multirow{2}{*}{$\mathbf{T}$} & \multirow{2}{*}{ Sig. (2-tailed) } \\
\hline & Pre & Post & & & & & \\
\hline Domain Fisik & 58,01 & 58,74 & 100 & 0,555 & 0,000 & $-0,710$ & 0,479 \\
\hline Domain Mental & 55,97 & 57,49 & 100 & 0,618 & 0,000 & $-1,310$ & 0,193 \\
\hline Domain Sosial & 61,60 & 62,59 & 100 & 0,772 & 0,000 & $-1,073$ & 0,286 \\
\hline Domain Lingkungan & 65,77 & 69,58 & 100 & 0,783 & 0,000 & $-4,802$ & 0,000 \\
\hline
\end{tabular}

hal-hal yang dapat memengaruhi persepsi dan tingkah laku dalam minum obat dan pola hidup, pada saat konseling apoteker selalu mengingatkan, menyadarkan dan memotivasi pasien tentang pentingnya pengobatan yang sedang dijalani dan mengajak keluarga untuk ikut melakukan kontrol pada pasien.

Skizofrenia merupakan gangguan mental jangka panjang yang menyebabkan penderita mengalami halusinasi, delusi atau waham, kekacauan berpikir, dan perubahan perilaku, sehingga penderita skizofrenia mengalami kesulitan dalam membedakan kenyataan dan pikirannya sendiri. Hal ini ditunjukkan oleh hasil penelitian ini bahwa penderita skizofrenia tidak dapat bekerja dengan baik sehingga tidak memiliki pekerjaan (59\%). Kesulitan dalam proses berpikir ini juga mengganggu hubungan sosial penderita terutama dalam hubungan pernikahan. Dari hasil wawancara, sebagian besar perceraian terjadi akibat pasangan dari penderita skizofrenia tidak dapat menerima penyakit yang diderita oleh pasangannya.

Rumah Sakit Jiwa Menur merupakan Rumah Sakit Khusus Jiwa yang berjenis Tipe A yang menerima rujukan penderita skizofrenia dari seluruh pelayanan kesehatan di Jawa Timur sehingga sebesar $56 \%$ penderita skizofrenia yang berobat rawat jalan ke Rumah Sakit Jiwa Menur telah menderita skizofrenia lebih dari 5 tahun. Sebanyak $42 \%$ responden menjawab pernah mendapatkan informasi mengenai skizofrenia dari dokter maupun perawat yang merawat pasien, sedangkan $58 \%$ responden menyatakan tidak pernah mendapat informasi mengenai skizofrenia.

Tingkat kepatuhan minum obat penderita skizofrenia rawat jalan Rumah Sakit Jiwa Menur Surabaya diukur dengan menggunakan kuesioner MARS yang terdiri atas 10 butir pertanyaan. Hasil penelitian ini menunjukkan bahwa presentase tingkat kepatuhan minum obat penderita skizofrenia pada saat pretest mayoritas masih berkategori rendah yakni $63 \%$, sedangkan presentase tingkat kepatuhan minum obat sedang yakni $36 \%$ dan tinggi $1 \%$. Setelah dilakukan konseling oleh apoteker (posttest), terdapat peningkatan yang bermakna pada presentase tingkat kepatuhan minum obat, yaitu tingkat kepatuhan rendah menjadi 59\%, kepatuhan sedang 40\% dan kepatuhan tinggi $1 \%$. Hal ini kemungkinan dapat terjadi disebabkan penderita skizofrenia rawat jalan di Rumah Sakit Jiwa Menur berasal dari seluruh daerah di Jawa Timur yang memiliki budaya atau kebiasaan di dalam kehidupan sehari-hari, seperti cara pandang terhadap penderita skizofrenia, tingkat pengetahuan atau pemahaman tentang apa itu skizofrenia dan pengobatannya, kondisi sosial-ekonomi atau kedudukan seseorang di masyarakat, serta dapat dipengaruhi pula oleh faktor kemampuan finansial yang sangat bervariasi. Hasil penelitian ini juga menunjukkan bahwa konseling oleh apoteker berpengaruh dalam meningkatkan tingkat kepatuhan dari rendah menjadi sedang. Penelitian Naafi et al. pada tahun 2016 di Rumah Sakit Jiwa Prof. Dr. Soerojo Magelang menyatakan bahwa tingkat kepatuhan pasien sedang sebesar $90 \%$, tinggi $7,5 \%$ dan rendah $2,5 \% .^{15}$

Hasil penelitian ini menunjukkan bahwa konseling oleh apoteker berpengaruh secara signifikan terhadap tingkat kepatuhan minum 
obat. Hal ini sesuai dengan penelitian yang dilakukan oleh Mishra et al. pada tahun 2017 yang menyatakan bahwa diikutsertakannya apoteker sebagai tim dalam perawatan pasien skizofrenia secara langsung di India dapat membantu meningkatkan kepatuhan minum obat dan kualitas hidupnya. ${ }^{17}$

Skizofrenia merupakan penyakit kronis yang kondisi fisik penderitanya cenderung tetap dan tidak ada perubahan. Penelitian oleh Gomes et al. pada tahun 2016 menyatakan bahwa pasien rawat jalan dengan skizofrenia mempunyai kualitas hidup lebih buruk serta aktivitas fisik yang lebih rendah dibanding dengan kontrol sehat. ${ }^{18}$

Hasil penelitian ini menunjukkan bahwa pada domain fisik kualitas hidup responden, yakni domain yang berhubungan dengan kondisi fisik penderita skizofrenia dalam kehidupan sehari-hari, contohnya kemampuan bekerja, bergerak, mengatur waktu istirahat, serta kondisi sakit fisik penderita sebelum dan setelah dilakukan konseling oleh apoteker tidak terdapat perbedaan yang bermakna ( $>0,05)$. Sama halnya pada domain mental/ psikologi kualitas hidup responden, dalam hal ini yakni mencakup keadaan mental yang mengarah pada ketidakmampuan individu dalam menyesuaikan diri terhadap tuntutan perkembangan, baik dari dalam maupun luar sesuai kemampuan dirinya, antara sebelum dan setelah dilakukan konseling oleh apoteker juga tidak terdapat perbedaan yang bermakna $(\mathrm{p}>0,05)$. Hal ini disebabkan oleh gangguan otak serius pada penderita skizofrenia yang memengaruhi cara dalam berpikir, bertindak, mengekspresikan emosi, memahami realitas dan berhubungan dengan orang lain. ${ }^{19}$ Domain sosial kualitas hidup responden yang meliputi hubungan pribadi dan dukungan sosial juga tidak memiliki perbedaan antara sebelum dan setelah dilakukan konseling oleh apoteker ( $>0,05)$. Penelitian Mohandoss pada tahun 2017 menyatakan bahwa pasien skizofrenia dibandingkan dengan orang normal memiliki nilai kualitas hidup yang lebih rendah dan memerlukan perhatian lebih pada domain fisik dan domain sosial. ${ }^{20}$

Di sisi lain, pada domain lingkungan yang dalam hal ini mencakup tempat tinggal individu, keamanan dan keselamatan fisik, kesempatan untuk mendapatkan informasi dan keterampilan baru, serta melakukan kegiatan menyenangkan di waktu luang, terdapat perbedaan bermakna antara sebelum dilakukan konseling oleh apoteker dan setelahnya. Hal ini disebabkan penderita skizofrenia merasa aman dan puas dengan lingkungan tempat tinggal dan berada ditengah-tengah keluarga yang memahami mereka. Dukungan keluarga sangat penting dalam menciptakan perasaan aman dan puas dengan lingkungan tempat tinggal penderita skizofrenia. Penelitian oleh Galuppi et al. pada tahun 2010 menyatakan bahwa lebih dari $70 \%$ respondennya puas dengan lingkungan tempat tinggal mereka. ${ }^{21}$

Berdasarkan hasil perhitungan SPSS versi 23 terhadap data mean pre dan post konseling pada domain kualitas hidup, konseling oleh apoteker hanya efektif meningkatkan kualitas hidup terkait domain lingkungan penderita skizofrenia rawat jalan di Rumah Sakit Jiwa Menur. Hal ini disebabkan apoteker sebagai pihak di lingkungan pasien melalui konseling yang diberikan berhasil memotivasi pasien sehingga pasien merasa mendapat dukungan untuk meningkatkan kepatuhan minum obat $(\mathrm{p}<0,05)$.

Limitasi pada penelitian ini terletak pada proses komunikasi dengan responden yang merupakan pasien rawat jalan yang menderita skizofrenia. Untuk mengatasi limitasi yang ada, ketika responden telah terpilih, peneliti meminta dokter psikiatri untuk memastikan bahwa responden dinyatakan mampu menjadi responden penelitian ini.

\section{Simpulan}

Pemberian konseling yang dilakukan oleh 
apoteker memiliki pengaruh terhadap tingkat kepatuhan minum obat pasien skizofrenia rawat jalan dan hanya efektif meningkatkan kualitas hidup terkait domain lingkungan, namun tidak memiliki pengaruh pada domain fisik, mental, dan sosial-ekonomi.

\section{Pendanaan}

Penelitian ini tidak didanai oleh sumber hibah manapun.

\section{Konflik Kepentingan}

Seluruh penulis menyatakan tidak terdapat potensi konflik kepentingan dengan penelitian, kepenulisan (authorship), dan atau publikasi artikel ini.

\section{Daftar Pustaka}

1. Kementerian Kesehatan Republik Indonesia. Undang-undang Republik Indonesia Nomor 18 Tahun 2014 Tentang Kesehatan Jiwa. Jakarta: Kementerian Kesehatan Republik Indonesia; 2014.

2. Barbato A. Schizophrenia and public health. Nations for mental health. Geneva: World Health Organization; 1998.

3. Badan Penelitian dan Pengembangan Kesehatan Kementerian Kesehatan Republik Indonesia. Riset Kesehatan Dasar Tahun 2013. Jakarta: Kementerian Kesehatan Republik Indonesia; 2013.

4. Suzuki T, Uchida H, Takeuchi H, Tsuboi T, Hirano J, Mimura M. A review on schizophrenia and relapse-a quest for user-friendly psychopharmacotherapy. Hum Psychopharm Clin. 2014;29(5):414 26. doi: 10.1002/hup.2421

5. Tarutani S, Kikuyama H, Ohta M, Kanazawa T, Okamura T, Yoneda H. Association between medication adherence and duration of outpatient treatment in patients with schizophrenia. Psychiatry Investig.
2016;13(4):413-9. doi: 10.4306/pi.2016.1 3.4 .413

6. Salazar-Ospina A, Amariles P, Benjumea DM, Gutierrez F, Faus MJ, et al. Effectiveness of the Dader Method for pharmaceutical care in patients with bipolar I disorder: EMDADER-TAB: Study protocol for a randomized controlled trial. Trials. 2014;15(52):1-10. doi :10.1186/1745 $-6215-15-174$

7. Rubio-Valera M, Chen TF, O'Reilly CL. New roles for pharmacists in community mental health care: A narrative review. Int J Environ Res Public Health. 2014;11(3): 10967-90. doi: 10.3390/ijerph111010967.

8. Rickles NM, Dube GL, Mccarter A, Olshan JS. Relationship between attitudes toward mental illness and provision of pharmacy services. J Am Pharm Assoc. 2010;50(6):704-13. doi: 10.1331/JAPhA. 2010.09042

9. Dhubhlaing CN, Young A, Sahm LJ. Impact of pharmacist counselling on clozapine knowledge. Schizophr Res Treatment. 2017;2017:6120970.

10. Reilly CLO, Bell JS, Kelly PJ, Chen TF. Exploring the relationship between mental health stigma, knowledge and provision of pharmacy services for consumers with schizophrenia. Res Soc Adm Pharm. 2015;11(3):e101-9. doi: 10.1 016/j.sapharm.2013.04.006.

11. Valenstein M, Kavanagh J, Lee T, Reilly P, Dalack GW, Grabowski J, et al. Using a pharmacy-based intervention to improve antipsychotic adherence among patients with serious mental illness. Schizophr Bull. 2011;37(4):727-36. doi: 10.1093/schbul/sb p121.

12. Panesar K. Barriers to counseling patients with mental health disorders. US Pharm. 2016;41(11):30-3.

13. Aaltonen SE, Laine NP, Volmer D, Gharat MS, Muceniece R, Vitola A, et al. Barriers to medication counselling for people with 
mental health disorders: A six country study. Pharm Pract. 2010;8(2):122-31.

14. Barkhof E, Meijer CJ, Sonneville LMJ De, Linszen DH, de Haan L. The effect of motivational interviewing on medication adherence and hospitalization rates in nonadherent patients with multiepisode schizophrenia. Schizophr Bull. 2013;39(6):1242-51. doi: 10.1093/schbu $1 / \mathrm{sbt} 138$.

15. Naafi A, Perwitasari DA, Darmawan E. Medication adherence of schizophrenia outpatients in Prof. Dr. Soerojo Mental Hospital Magelang. Kartika J Ilm Farm. 2016;4(2):7-12. doi: 10.26874/kjif.v4i2.60

16. World Health Organization. The World Health Organization Quality of Life (WHOQOL)-BREF; 2004.

17. Mishra A, Krishna GS, Sravani A, Kurian TD, Kurian J, Ramesh M, et al. Impact of pharmacist-led collaborative patient education on medication adherence and quality of life of schizophrenia patients in a tertiary care setting. Bull Fac Pharmacy,
Cairo Univ. 2017;55(2):345-9. doi: 10.10 16/j.bfopcu.2017.08.001

18. Gomes E, Bastos T, Probst M, Riberio JC, Silva G, Corredeira R. Quality of life and physical activity levels in outpatients with schizophrenia. Braz J Psychiatry. 2016;38(2):157-60. doi: 10.1590/1516-4 446-2015-1709.

19. Sadock BJ, Sadock VA. Kaplan and sadock's pocket handbook of clinical psychiatry, 5th Edition. USA: Wolters Kluwer Health, Lippincont Williams \& Wilkins; 2010.

20. Mohandoss AA. Quality of life in schizophrenic patients: Comparative study from South India. J Dr NTR Univ Heal Sci. 2017;6(4):224-31. doi: 10.4103/227 7-8632.221523

21. Galuppi A, Turola MC, Nanni MG, Mazzoni P, Grassi L. Schizophrenia and quality of life: How important are symptoms and functioning? Int $\mathrm{J}$ Ment Health Syst. 2010;4:31. doi: 10.1186/1752 -4458-4-31. 